\title{
Original article \\ Improved exercise capacity in the heat followed by coconut water consumption
}

\author{
Orlando Laitano \\ Federal University of Vale do São Francisco, Petrolina, Brazil \\ Steven J. Trangmar \\ Brunel University, London, UK \\ Denise de Melo Marins \\ Eveline Soares Menezes \\ Gisienne da Silva Reis \\ Federal University of Vale do São Francisco, Petrolina, Brazil
}

\begin{abstract}
The aim of the present study was to assess the effects of prior ingestion of coconut water on fluid retention and exercise capacity in the heat as well as signs of gastrointestinal distress. Eight physically active men were recruited (age $23 \pm 3$ years, height $176 \pm 6 \mathrm{~cm}$, body mass $78 \pm 7 \mathrm{~kg}$ ) and performed three exercise capacity trials on a cycle ergometer in the heat $\left(34 \pm 1{ }^{\circ} \mathrm{C}\right)$ after the ingestion of one of the following drinks: a) plain water $(P W)$, b) flavored drink $(F D)$, and c) coconut water $(C W)$. Ingestion of $C W$ resulted in a longer time to exhaustion $(p=0.029)$. Likewise, participants achieved a higher heart rate in the $\mathrm{CW}$ session when compared to the other trials $(P W 183 \pm 5 \mathrm{bpm}, F D$ $184 \pm 8 \mathrm{bpm}$, and $C W 189 \pm 8 \mathrm{bpm}, p<0.05)$ and a reduced urine output after the coconut water ingestion $(P W 214 \pm 85$ $\mathrm{ml}, F D 267 \pm 90 \mathrm{ml}$, and $C W 161 \pm 73 \mathrm{ml}, p<0.05$ ) indicating a higher fluid retention of coconut water in comparison to plain water and the flavored drink. These results demonstrate that previous ingestion of coconut water improves exercise capacity in the heat and provide a reduced urine output in comparison to plain water and flavored drink. Also there is no evidence for GI distress.
\end{abstract}

Keywords: hydration, performance, temperature

Resumo - O objetivo do presente estudo foi avaliar os efeitos da ingestão prévia de água de coco sobre a retenção de líquidos e capacidade de resistência ao exercício no calor, bem como sinais de desconforto gastrointestinal. Oito homens fisicamente ativos foram recrutados (idade $23 \pm 3$ anos, altura $176 \pm 6 \mathrm{~cm}$, massa corporal $78 \pm 7 \mathrm{~kg}$ ) e realizaram três sessões de capacidade de exercício em uma bicicleta ergométrica no calor $\left(34 \pm 1^{\circ} \mathrm{C}\right)$ após a ingestão de uma das seguintes bebidas: a) água pura (PW), b) bebida com sabor (FD), e c) água de coco (CW). A ingestão de $\mathrm{CW}$ resultou num maior tempo até a exaustão $(p=0,029)$. Da mesma forma, os participantes alcançaram uma frequência cardíaca mais alta na sessão de CW quando comparado com as outras sessões (PW $183 \pm 5$ bpm, FD $184 \pm 8$ bpm, e CW $189 \pm 8$ bpm, $p$ $<0,05$ ) e uma taxa de produção de urina reduzida após a ingestão de água de coco (PW $214 \pm 85 \mathrm{ml}$, FD $267 \pm 90 \mathrm{ml}$, e CW $161 \pm 73 \mathrm{ml}, p<0,05$ ), indicando uma maior retenção de líquidos na sessão água de coco em comparação com água pura e bebida com sabor. Estes resultados demonstram que a ingestão prévia de água de coco melhora a capacidade de exercício no calor e proporciona uma menor produção de urina em comparação com a água pura e bebida com sabor. Também não houve nenhuma evidência de desconforto gastrointestinal.

Palavras-chave: hidratação, desempenho, temperatura

Resumen-El objetivo del presente estudio fue evaluar los efectos de la ingesta previa de agua de coco en la retención de líquidos y la capacidad de ejercicio al calor, así como señales de malestar gastrointestinal. Ocho hombres físicamente activos fueron reclutados (edad $23 \pm 3$ años, altura $176 \pm 6 \mathrm{~cm}$, la masa corporal de $78 \pm 7 \mathrm{~kg}$ ) y se realizaron tres ensayos de capacidad de ejercicio en un cicloergómetro con el calor $\left(34 \pm 1^{\circ} \mathrm{C}\right)$ después de la ingestión de una de las siguientes bebidas: a) agua potable (PW), b) bebida con sabor (FD), y c) el agua de coco (CW). La ingestión de CW dio lugar a un tiempo más largo hasta el agotamiento $(p=0,029)$. Del mismo modo, los participantes lograron una frecuencia cardíaca mayor en el CW en comparación con los otros ensayos (PW $183 \pm 5$ lpm, FD $184 \pm 8$ latidos por minuto, y CW $189 \pm$ 8 latidos por minuto, $p<0,05$ ) y una disminución del gasto urinario después del coco la ingestión de agua (PW $214 \pm$ $85 \mathrm{ml}$, FD $267 \pm 90 \mathrm{ml}$, y CW $161 \pm 73 \mathrm{ml}, p<0,05$ ) que indica una retención de líquidos mayor de agua de coco en comparación con agua pura y la bebida con sabor. Estos resultados demuestran que la ingesta previa de agua de coco 
mejora la capacidad de ejercicio en el calor y proporciona una disminución del gasto urinario en comparación con agua corriente y la bebida con sabor. Además, no hay evidencia de malestar gastrointestinal.

Palabras clave: la hidratación, rendimiento, temperatura

\section{Introduction}

The maintenance of hydration status is crucial for the athlete and may have a direct impact on physical performance (Lopez et al., 2011; Rothenberg \& Panagos 2008). While for some people the ingestion of water is enough to maintain hydration status, those involved in vigorous physical activity, particularly in a hot environment, may need drinks containing carbohydrate and electrolytes (von Duvillard, Arciero, Tietjen-Smith, \& Alford, 2008). It is well established that carbohydrate ingestion during exercise can increase exercise capacity and improve time trial performance (Jeukendrup, 2013). Commercially available sports drinks may adequately maintain hydration status in athletic populations; however, alternatives to these are available and may also maintain hydration status in those exercising in hot weather. Furthermore, drinks containing high amounts of carbohydrate and electrolyte may result in a hypertonic state, which may cause gastrointestinal (GI) distress such as diarrhea, bloating, nausea, vomiting, and abdominal cramps (Evans, Shirreffs, \& Maughan, 2009; Stuempfle, Hoffman, \& Hew-Butler, 2013).

Coconut water $(\mathrm{CW})$ is naturally occurring and widely consumed in tropical countries due to its beneficial properties to health, some of which are based on cultural/traditional beliefs (Yong, Ge, Ng, \& Tan, 2009). Other aspects that may involve preference for $C W$ instead of other hydration solutions are the ease of obtaining the drink, palatability and personal predilection. Coconut water's main electrolyte is potassium $\left(\mathrm{K}^{+}\right)$, while the alternative commercial sports drinks contain sodium $\left(\mathrm{Na}^{+}\right)$ as the main electrolyte. While the effects of $\mathrm{Na}^{+}$-containing drink on fluid retention and exercise capacity in the heat have been previously demonstrated (Sims, Rehrer, Bell, \& Cotter, 2007), the effects of $\mathrm{K}^{+}$-containing drinks such as $C W$ remain unknown. Likewise, there is a lack of studies investigating the effects of the previous ingestion of $C W$ (e.g., pre-hydration) on fluid retention and GI symptoms during exercise in the heat. Therefore, consuming $C W$ prior to exercising in the heat may improve exercise capacity in the heat despite the risk of GI distress due to higher drink osmolality. Thus, the objective of this study was to determine the effect of previous consumption of $C W$ on urine output, GI distress and cycling capacity in the heat.

\section{Methods}

\section{Participants}

Eight healthy males were recruited to the study. Participants' physical characteristics are described in Table 1. All participants took part in recreational activities two to three times per week (e.g., jogging, cycling, and gym). None of them were engaged in regular training for a particular sporting event. All participants were naturally acclimatized to the heat since they lived in a tropical country. The study protocol was approved by the University's Ethical Committee (NO: 415994). Participants visited the lab on four occasions separated by at least 5 and at most 7 days. They were also blind to the real objectives of the study and were informed that the aim of the study was to compare the effect of different types of drink upon exercise capacity in the heat.

\section{Preliminary visit}

Upon arrival on the first visit, participants were informed about all risks and benefits associated with the protocol and provided their consent term. Thereafter, participants' anthropometrical data were recorded and subsequently they performed an incremental cycling test to exhaustion, with constant cadence of $70 \mathrm{rpm}$, to determine the workload of the following exercise capacity trial $\left(60 \% P_{\text {max }}\right)$. Initial workload was set at $30 \mathrm{~W}$ with increments of $30 \mathrm{~W} / \mathrm{min}$ until exhaustion. The incremental test was performed in the heat of a room with a temperature of $34^{\circ} \mathrm{C}$ and $\sim 55 \%$ relative humidity. In this visit, participants were instructed to record their $24 \mathrm{~h}$ food intake and were asked to repeat the same intake before the following visits.

\section{Experimental procedure}

For the following three visits, participants ingested a total of $10 \mathrm{ml} / \mathrm{kg}$ of body mass of plain water (Mineral Water Indaiá, Brazil), orange flavored drink (Clight, Brazil) or commercially available coconut water (Kerococo, Pepsico, Brazil). The drink order was randomized in this study. The total drink volume was divided in seven aliquots and given to participants every $10 \mathrm{~min}$ for a period of one hour. The carbohydrate, sodium, and potassium content in addition to the specific gravity of the drinks are described in Table 2. Urine samples were collected before the ingestion of the drinks and after the time to exhaustion test in each

Table 1. Participants' physical characteristics.

\begin{tabular}{|c|c|}
\hline & Mean \pm SD \\
\hline Age (years) & $23 \pm 4$ \\
\hline Height $(\mathrm{cm})$ & $176 \pm 6$ \\
\hline Body mass (kg) & $78 \pm 7$ \\
\hline$\Sigma$ skinfolds & $90 \pm 23$ \\
\hline Maximal power output $\left(\mathrm{P}_{\max }\right)$ & $352 \pm 30$ \\
\hline $\mathrm{HR}_{\max }(\mathrm{bpm})$ & $187 \pm 9$ \\
\hline
\end{tabular}

$\Sigma=$ sum of the following skinfolds: supra-spinal, triceps, biceps, chest, abdominal, suprailiac and thigh. The power output and heart rate values were recorded at the end of the incremental test. 
Table 2. Drink composition.

\begin{tabular}{lllll}
\hline & $\begin{array}{l}\text { Carbohydrate } \\
(\mathbf{g})\end{array}$ & $\begin{array}{l}\text { Sodium } \\
(\mathbf{m g})\end{array}$ & $\begin{array}{l}\text { Potassium } \\
(\mathbf{m g})\end{array}$ & $\begin{array}{l}\text { Specific } \\
\text { gravity }\end{array}$ \\
\hline Plain water & 0 & 0 & 0 & 1.000 \\
Flavored drink & 0.7 & 10 & 0 & 1.002 \\
Coconut water & 11 & 40 & 300 & 1.026 \\
\hline
\end{tabular}

Carbohydrate, sodium and potassium concentrations reported by the manufacturers per $200 \mathrm{ml}$ of solution. Specific gravity of each drink was determined in triplicate by refractometry (Biobrix, model 301).

experimental session for the assessment of urine output and urine specific gravity through an analogical refractometer (Biobrix, model 301). The urine output after a protocol of fluid ingestion has been used as a marker of fluid retention of a given drink in exercise settings (Evans et al., 2009; Maughan, McArthur, \& Shirreffs, 1996; Merson, Maughan, \& Shirreffs, 2008; Shirreffs, Aragón-Vargas, Keil, Love, \& Phillips, 2007; Shirreffs, Taylor, Leiper, \& Maughan 1996) since there is an inverse relationship between fluid retention and urine output. Fluid balance was calculated by subtracting the total amount of fluid ingested from the sweat rate and urine output after the time to exhaustion test in each session. Sweat rate during the time to exhaustion test in the heat was calculated as the difference in body mass in each session, corrected by the time each participant took to complete the test.

\section{Exercise capacity in the heat}

The time to exhaustion test in the heat started 20 minutes after the ingestion of the last aliquot of the respective drink. Before starting the test, participants' self-inserted a rectal thermister (Physitemp, New Jersey, USA) $10 \mathrm{~cm}$ beyond the anal sphincter. Participants' proceeded to start cycling at $60 \% P_{\text {max }}$, as previously measured in the incremental test. This workload was chosen because a previous study used similar intensity to determine the effects of previous ingestion of $\mathrm{Na}^{+}$-containing drink on subsequent time to exhaustion test in the heat (Sims, Rehrer, Bell, \& Cotter, 2007). Participants kept a steady cadence of between 60 and $70 \mathrm{rpm}$ and heart rate ( $\mathrm{bpm}$ ) and rectal temperature were mo-

Table 3. Change in body mass, total fluid ingestion, urine output, urine specific gravity (USG), rectal temperature $\left(\mathrm{T}_{\text {rec }}\right)$ and heart rate at the end of the exercise capacity test in the heat.

\begin{tabular}{llll}
\hline & Plain water & Flavored drink & Coconut water \\
\hline $\begin{array}{l}\Delta \text { Body mass } \\
(\mathrm{kg})\end{array}$ & $-1.0 \pm 0.4$ & $-0.9 \pm 0.2$ & $-0.8 \pm 0.2$ \\
$\begin{array}{l}\text { Fluid ingestion } \\
(\mathrm{ml})\end{array}$ & $783 \pm 74.1$ & $788 \pm 72.3$ & $790 \pm 75.4$ \\
$\begin{array}{l}\text { Urine output } \\
(\mathrm{ml})\end{array}$ & $214 \pm 85$ & $267 \pm 90$ & $161 \pm 73^{\#}$ \\
Sweat rate $(\mathrm{L} / \mathrm{h})$ & $2.2 \pm 1$ & $1.8 \pm 0,7$ & $1.1 \pm 0,3$ \\
USG & $1006 \pm 7$ & $1003 \pm 2$ & $1007 \pm 6$ \\
$\left.\operatorname{Trec}^{\circ} \mathrm{C}\right)$ & $37.5 \pm 0.6$ & $37.6 \pm 0.6$ & $37.9 \pm 0.7$ \\
$\mathrm{HR}_{\text {end }}(\mathrm{bpm})$ & $183 \pm 5$ & $184 \pm 8$ & $189 \pm 8^{*}$ \\
\hline
\end{tabular}

*Different from plain water. ${ }^{*}$ Different from flavored drink $p<0.05$ nitored throughout the test. Participants were verbally encouraged to achieve maximal effort during the test that was halted when participants were not able to maintain a cadence above $60 \mathrm{rpm}$ and when ratings of perceived exertion were close to 20 (Borg scale). Participants were asked about gastrointestinal discomfort throughout the exercise capacity test by using an analogical GI distress scale described elsewhere (Perrone et al. 2005). All tests were performed in a warm room heated to $34 \pm 1{ }^{\circ} \mathrm{C}$ and $\sim 55 \%$ relative humidity.

\section{Statistical analysis}

Statistical analysis was performed by using the Statistical Package for Social Science for Windows (SPSS 16.0). Data are reported as mean \pm standard deviation (SD). One way analysis for repeated measures (ANOVA) was employed to compare means with Bonferroni's correction where appropriate.

\section{Results}

\section{Body mass and rectal temperature}

Body mass decreased from rest to the end of exercise in the heat, in all drink trials $\left(P W_{\text {pre }}=78.8 \pm 7.4 P W_{\text {post }}=77.8 \pm 7.2\right.$; $F D_{\text {pre }}=79.3 \pm 7.3 F D_{\text {post }}=78.4 \pm 7.2 ; C W_{\text {pre }}=79.4 \pm 7.7 C W_{\text {post }}=$ $78.6 \pm 7.7 \mathrm{~kg} ; p<0.05)$. Conversely, rectal temperature increased from the beginning to the end of the exercise capacity test in the heat in all drink trials $\left(P W=36.9 \pm 0.4-37.5 \pm 0.6^{\circ} \mathrm{C} ; F D\right.$ $=36.8 \pm 0.4-37.6 \pm 0.6^{\circ} \mathrm{C} ; C W=36.8 \pm 0.3-37.9 \pm 0.7^{\circ} \mathrm{C}$, $p<0.05)$. However, no differences were observed between the rectal temperatures achieved by the time of fatigue in the heat independent of the drink ingested (Table 3).

\section{Urine output, sweat rate and fluid balance}

Urine output was reduced in the $C W$ trial in comparison to $P W$ and $F D$ trials $(p<0.05$, Table 3$)$. However, sweat rate and net fluid balance were similar among all three drink trials (Table 3).

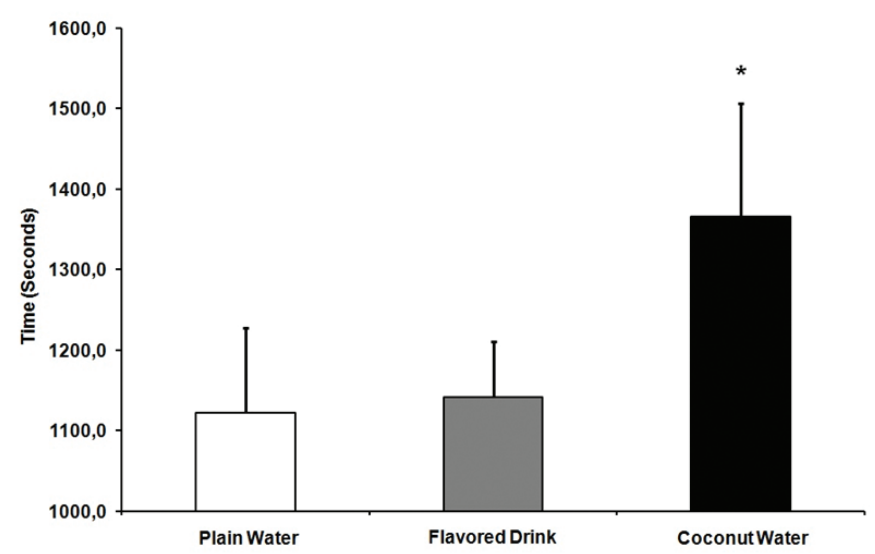

Figure 1. Cycling time to exhaustion (seconds) in the heat $\left(34^{\circ} \mathrm{C}\right)$ after ingestion of plain water, flavored drink and coconut water. ${ }^{*}$ Different from plain water and flavored drink, $p<0.05$. 


\section{Rate of perceived exertion, exercise capacity in the heat, heart rate and GI distress}

As expected, there was a significant increase in RPE from the beginning to the end of exercise in the heat in all drink trials $(p<0.05)$. However, no differences were observed in RPE between trials. As observed in Figure 1, there was a greater exercise capacity in the heat with previous consumption of $C W$ in comparison to $P W$ and $F D(p<0.05)$. Also, at fatigue, there was a higher maximal heart rate in comparison to plain water $(p<0.05$, Table 3$)$. There was no report of GI distress regardless of the drink ingested.

\section{Discussion}

To our knowledge, this is the first study to systematically measure the effects of previous consumption of coconut water upon exercise capacity in the heat. The main findings of the present study were threefold: 1) previous ingestion of $C W$ improved exercise capacity in the heat; 2) urine output was reduced in the $C W$ trial and 3) there were no signs of GI distress after the consumption of $C W$.

In the present study, previous ingestion of $C W$ improved exercise capacity in the heat. Conversely, a recent study where subjects rehydrated with $C W$ after a dehydration protocol, did not find significant differences following a treadmill time to exhaustion test (Kalman, Feldman, Krieger, \& Bloomer, 2012). The reason for this conflicting result may be explained by the fact that participants in the present study consumed $C W$ before exercising in the heat, whereas in Kallman et al. participants consumed $C W$ after a dehydration protocol and before exercising in temperate room temperature. It is well known that exercise in the heat increases the reliance on anaerobic pathways (Dimri, Malhota, Sen, Kumar, \& Arora, 1980; Parkin, Carey, Zhao, \& Febbraio, 1999). Therefore, it is possible to speculate that consuming $C W$ before exercising in the heat may improve performance, whereas in temperate weather it may not. Another possible reason for the improvement in performance observed with the previous consumption of $C W$ was the presence of carbohydrate. It is well established in the literature that carbohydrate consumption improves performance, particularly when exercise is performed in hot ambient conditions (Carter, Jeukendrup, Mundel, \& Jones, 2003; Jentjens et al., 2006). Nonetheless, because of its high osmolality and high potassium concentration, $\mathrm{CW}$ could have caused gastrointestinal distress negatively affecting subsequent performance in the heat. Therefore, the results of the present study suggest that previous consumption of coconut water does not cause gastrointestinal distress, despite the drink composition, and improves subsequent exercise capacity in the heat, probably due to its carbohydrate content.

The previous ingestion of $C W$ resulted in a smaller urine output, indicating a greater hydration capacity of $C W$. Exercise in the heat negatively affects performance in comparison to exercising in a temperate weather. This effect is in part due to a greater cardiovascular strain imposed by the competition for the available blood flow between skin and active muscles (González-Alonso, Crandall, \& Johnson, 2008). Therefore, the greater time to exhaustion and higher heart rate observed in the $C W$ trial may be explained by the greater fluid retention induced by the previous ingestion of $C W$ as shown by the reduced urine output. Furthermore, our results are aligned with other studies that demonstrated the efficacy of $C W$ to replenish the hydration status after exercise (Saat, Singh, Sirisinghe, \& Nawawi, 2002; Kalman et al., 2012), despite the fact that in the present study $C W$ was used as pre hydration strategy while in the abovementioned studies it was used as a rehydration solution. Accordingly, it is possible to speculate that $C W$ may work both as a pre and as a rehydration (after exercise) strategy. However, the consumption of $C W$ during an exercise session is still a matter of debate because of the risks of GI distress.

None of the participants in the current study presented signs of GI distress when ingesting $C W$ before cycling in the heat. Drink osmolality is a key factor in determining the rate of gastric emptying of a drink. When a drink is hyperosmotic it may promote the shift of fluids from the intravascular space into the gut causing gastrointestinal distress and dehydration (Evans et al., 2009). One concern about $C W$ ingestion during an exercise task is the risk of GI distress due to its elevated osmolality (Kalman et al., 2012). Therefore, we can assume that previous consumption of $C W$ may be safe, in terms of GI distress, to those exercising in the heat.

It is important to note that the majority of studies on $C W$ use commercially available $C W$ (Kalman et al., 2012; Saat et al., 2002), which may not correspond to the effects of $C W$ taken directly from the coconut. However, the composition of $C W$ obtained from the coconut is influenced by the time of harvesting, ambient temperature, soil irrigation and maturation time (Camargo \& Fagundes Neto, 1994). Nevertheless, studies using $C W$ obtained direct from the coconut (natural occurring) are warranted and a placebo drink should be included in the study design. Future studies should also include the analysis of serum electrolytes sodium and potassium to clarify the physiological relevance of a greater concentration of potassium seen in $C W$. Nonetheless, it is known that the addition of potassium to a rehydration solution might increase the retention of the solution (Yawata, 1990) possibly by increasing water retention in the intracellular space, (Shirreffs, Aragon-Vargas, Keil, Love, \& Phillips, 2007), but some investigators (Shirreffs, Watson, \& Maughan, 2007) have found no effect of adding potassium to a rehydration solution.

In conclusion, the present results demonstrate that previous ingestion of $C W$ improves exercise capacity in the heat; provides a greater fluid retention in comparison to plain water and flavored drink; and causes no gastrointestinal distress.

\section{References}

Camargo, A. A. \& Fagundes Neto, U. (1994). Transporte transepitelial de água, sódio e glicose da água de coco, em alças jejunais de ratos submetidos à perfusão in vivo, nos diferentes estágios de maturação do coco. Jornal de Pediatria (Rio de Janeiro), 70(2), 100-104.

Carter, J., Jeukendrup, A. E., Mundel, T., \& Jones, D. A. (2003) Carbohydrate supplementation improves moderate and high-intensity exercise in the heat. Plufgers Archives, 446(2), 211-219. 
Dimri, G. P., Malhotra, M. S., Sen Gupta, J., Kumar, T. S., \& Arora, B.S. (1980). Alterations in aerobic-anaerobic proportions of metabolism during work in heat. European Journal of Applied Physiology and Occupational Physiology, 45(1), 43-50.

Evans, G. H., Shirreffs, S. M., \& Maughan, R. J. (2009). Postexercise rehydration in man: the effects of carbohydrate content and osmolality of drinks ingested ad libitum. Applied Physiology Nutrition and Metabolism, 34(4), 785-793.

González-Alonso, J., Crandall, C. G., \& Johnson, J. M. (2008). The cardiovascular challenge of exercising in the heat. Journal of Physiology, 586(1), 45-53.

Jentjens, R. L., Underwood, K., Achten, J., Currell, K., Mann, C. H., \& Jeukendrup, A.E. (2006). Exogenous carbohydrate oxidation rates are elevated after combined ingestion of glucose and fructose during exercise in the heat. Journal of Applied Physiology, $100(3), 807-816$.

Jeukendrup, A. (2013). Multiple transportable carbohydrates and their benefits. Sports Science Exchange, 26(108), 1-5.

Kalman, D. S., Feldman, S., Krieger, D. R., \& Bloomer, R. J. (2012). Comparison of coconut water and a carbohydrate-electrolyte sport drink on measures of hydration and physical performance in exercise-trained men. Journal of International Society of Sports Nutrition, 9(1), 1-10.

Lopez, R. M., Casa, D. J., Jensen, K. A., DeMartini, J. K., Pagnotta, K. D., Ruiz, R. C., ... Maresh, C. M. (2011). Examining the influence of hydration status on physiological responses and running speed during trail running in the heat with controlled exercise intensity. Journal of Strength and Conditioning Research, 25(11), 2944-2954.

Maughan, R. J., McArthur, M., \& Shirreffs, S. M. (1996). Influence of menstrual status on fluid replacement after exercise induced dehydration in healthy young women. British Journal of Sports Medicine, 30(1), 41-47.

Merson, S. J., Maughan, R. J., \& Shirreffs, S. M. (2008). Rehydration with drinks differing in sodium concentration and recovery from moderate exercise-induced hypohydration in man. European Journal of Applied Physiology, 103(5), 585-594.

Parkin, J. M., Carey, M. F., Zhao, S., \& Febbraio, M. A. (1999). Effect of ambient temperature on human skeletal muscle metabolism during fatiguing submaximal exercise. Journal of Applied Physiology, 86(3), 902-908.

Perrone, C., Laitano, \& O., Meyer, F. (2005). Effect of carbohydrate ingestion on the glycemic response of type 1 diabetic adolescents during exercise. Diabetes Care, 28(10), 2537-2538.

Rothenberg, J. A. \& Panagos, A. (2008). Musculoskeletal performance and hydration status. Current Reviews in Musculoskeletal Medicine, 1(2), 131-136.

Saat, M., Singh, R., Sirisinghe, R. G., \& Nawawi, M. (2002). Rehydration after exercise with coconut water, carbohydrate-electrolyte beverage and plain water. Journal of Physiological Anthropology, 21(2), 93-104.

Shirreffs, S. M., Aragon-Vargas, L. F., Keil, M., Love, T. D., \& Phillips, S. (2007). Rehydration after exercise in the heat: a comparison of 4 commonly used drinks. International Journal of Sports Nutrition and Exercise Metabolism, 17(3), 244-258.

Shirreffs, S. M., Taylor, A. J., Leiper, J. B., \& Maughan, R. J. (1996). Post-exercise rehydration in man: effects of volume consumed and drink sodium content. Medicine and Science in Sports and Exercise, 28(10), 1260-1271.

Shirreffs, S. M., Watson, P., \& Maughan, R. J. (2007b). Milk as an effective post-exercise rehydration drink. British Journal of $\mathrm{Nu}$ trition, 98(1), 173-180.

Sims, S. T., Rehrer, N. J., Bell, M. L., \& Cotter, J. D. (2007). Preexercise sodium loading aids fluid balance and endurance for women exercising in the heat. Journal of Applied Physiology, 103(2), 534-541.
Stuempfle KJ, Hoffman MD, Hew-Butler T. (2013) Association of gastrointestinal distress in ultramarathoners with race diet. International Journal of Sports Nutrition and Exercise Metabolism, 23(2), 103-109.

von Duvillard, S.P., Arciero, P. J., Tietjen-Smith, T., \& Alford, K. (2008). Sports drinks, exercise training, and competition. Current Sports Medicine Report, 7(4), 202-208.

Yawata, T. (1990). Effect of potassium solution on rehydration in rats: comparison with sodium solution and water. Japanese Journal of Physiology, 40(3), 369-381.

Yong, J. W., Ge, L., Ng, Y. F., \& Tan, S. N. (2009). The chemical composition and biological properties of coconut (Cocos nucifera L.) water. Molecules, 14(12), 5144-5164.

\section{Authors' note}

Orlando Laitano, Denise de Melo Marins, Eveline Soares Menezes, and Gisienne da Silva Reis are with the Federal University of Vale do São Francisco, Petrolina, Brazil.

Steven J. Trangmar is with the Centre for Sports Medicine and Human Performance, Brunel University, London, UK

\section{Corresponding author:}

Dr Orlando Laitano

Colegiado de Educação Física, UNIVASF

Av. José de Sá Maniçoba S/N, Centro, Petrolina 56304-205, PE, Brazil

E-mail: orlando.laitano@univasf.edu.br

\section{Acknowledgements}

We would like to thank Pepsico for providing the coconut water. Especially thanks go to Mr. João Gabriel Araújo for his technical support during data collection. Gisienne Reis was supported by a scholarship from Fundação de Amparo à Ciência e Tecnologia do Estado de Pernambuco (BIC 0455-4.09/11).

Manuscript received on September 8, 2013

Manuscript accepted on December 16, 2013

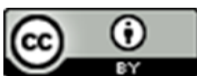

